\title{
THE EXPERIENCE OF RUPTURE AND THE HISTORY OF MEMORY
}

\author{
Brecht Deseure and Judith Pollmann
}

In the last three decades, the idea of modernity has become tightly bound to the study of historical consciousness. Having abandoned the notion that there is only one path to modernity, more and more scholars have come to define modernity above all as a cultural habitus. Modernity is now less about doing objectively 'modern' things than about a form of selfawareness that makes people think of themselves or others as modern. In this definition, modernity implies above all an awareness of change and a sense of the past as non-repeatable, in short a 'modern' form of historical consciousness. ${ }^{1}$

Although scholars have differing views on the pace and nature of the emergence of this sense of a non-repeatable past, nearly all of them share the notion of a chronologically irreversible transformation, somewhere between 1500 and 1900, of pre-modern into modern ways of making sense of the past. Typically, binary concepts are used to describe this transformation: from traditional to modern, from cyclical to linear, from continuous to discontinuous. Modern ways of dealing with the past are thus assumed not to have complemented but to have replaced pre-modern ones. ${ }^{2}$

Both modernists and early modernists have long argued that the key catalyst for such a transformation of attitudes towards time and the past is the experience of rupture and crisis. ${ }^{3}$ Schematically put, the argument

${ }^{1}$ Marshall Berman, All that is solid melts into air. The experience of modernity (1st ed. 1982, London: Penguin, 1988); Stuart Hall, 'Introduction', in Stuart Hall and Bram Gieben (eds.), Formations of modernity (Cambridge: Polity Press, 1992), 1-16, esp. 15; Christopher Bayly, The birth of the modern world, 1780-1914 (Malden and Oxford: Blackwell, 2004), 9-10.

2 E.g. Matei Calinescu, Five faces of modernity. Modernism, avant-garde, decadence, kitsch, postmodernism (Durham: Duke Univ Press, 1987), 13-35; Aleida Assmann, Erinnerungsräume. Formen und Wandlungen des kulturellen Gedächtnisses (Munich: Beck, 2006), 50-55.

3 Expressed e.g. by Eric Hobsbawm, 'The sense of the past' in his On history (Weidefeld and Nicholson; London 1997), 10-24, there $12-15$. This essay was first published as 'The social function of the past. Some questions', Past \& Present 55 (1972). Among early modernists e.g. Peter Burke, The Renaissance sense of the past (London: Arnold, 1969), 
goes as follows: episodes of social, economic and political upheaval bring about a sense of temporal change and uproot traditional past relationships. These experiences of crisis and change create the perception of a gap between the past and the present, in which the present seems no longer to reproduce what had come before but instead brings novelty and difference. As a result, a new conception of time arises in which time comes to be conceived of not as a cyclical movement but as a process of linear development.

Many theorists of memory have pointed to the age of revolutions of the late eighteenth century as the period in which this transformation was most evident. ${ }^{4}$ In doing so, they roughly follow the line of reasoning laid out by Reinhardt Koselleck in his Vergangene Zukunft of $1964 .{ }^{5}$ But whereas Koselleck emphasised the role of intellectuals in the forging of these changes, many of his readers have tended to see the pace of change itself as the catalyst for changing perceptions of the past. In doing so they have highlighted the age of revolutions in the late eighteenth century as a period of change so breathtaking that it forever changed people's perceptions of the relationship between past, present and future. ${ }^{6}$ The events of the revolutionary and Napoleonic periods so fundamentally disrupted traditional society that they affected the way people related to their pasts. Writings of the period testify to a heightened awareness of change; a feeling of being cut off from one's past manifested itself, along with the feeling of acceleration of time. The past rapidly grew into the 'foreign country'

18-19, 149-150; Keith Thomas, The perception of the past in early modern England. The Creighton Trust Lecture 1983 (London: University of London, 1984); Daniel Woolf, The social circulation of the past. English historical culture, 1500-1730 (Oxford: Oxford University Press, 2003). Modernist approaches surveyed in Jeffrey K. Olick and Joyce Robbins, 'Social memory studies. From "collective memory" to the historical sociology of mnemonic practices', Annual review of sociology 24 (1998), 105-140, esp. 115-116.

4 E.g.: Jacques Le Goff, Histoire et mémoire (1st ed. 1977, Paris: Gallimard, 1988), 74-75, 155-160, 252-253; Berman, All that is solid, 17; Paul Connerton, How societies remember (Cambridge: Cambridge University Press, 1989), 6-7; Richard Terdiman, Present past. Modernity and the memory crisis (Ithaca and London: Cornell University Press, 1993), 3-32; John R. Gillis, 'Memory and identity. The history of a relationship', in John R. Gillis (ed.), Commemorations. The politcs of national identity (Princeton: Princeton University Press, 1994), 3-24, there 7; Anthony D. Smith, Nationalism (Cambridge: Polity Press, 2001), 49-53; Frank Ankersmit, Sublime historical experience (Stanford: Stanford University Press, 2005).

5 Reinhart Koselleck, Vergangene Zukunft. Zur Semantik geschichtlicher Zeiten (Frankfurt am Main: Suhrkamp Verlag, 1979). See also the introduction to this volume.

6 Berman, All that is solid, 17; Terdiman, Present past, 3-32. 
it constituted for the people of the nineteenth century. ${ }^{7}$ As Richard Terdiman puts it:

In Europe in the period of the 1789-1815 Revolution, and particularly in France, the uncertainty of relation with the past became especially intense. In this period people experienced the insecurity of their culture's involvement with its past, the perturbation of the link to their own inheritance, as what I want to term a 'memory crisis': a sense that their past had somehow evaded memory, that recollection had ceased to integrate with consciousness. ${ }^{8}$

Terdiman is only one of many who continue to argue for the long-term impact of this rupture. Philosopher Frank Ankersmit has similarly argued that the experience of the Age of Revolutions became a catalyst for the emergence of new conceptions of the past. ${ }^{9}$ In his Stranded in the Present. Modern Time and the Melancholy of History (2004), Peter Fritzsche has shown how both autobiographical and literary texts in the nineteenth century were pervaded by a sense of a rift and ever faster change, and argued that nostalgia was one of its main results. ${ }^{10}$ Arianne Baggerman, in a Dutch context, found little evidence for nostalgia but nevertheless a great sense of change and novelty pervading the diaries and life-writings from the first half of the nineteenth century. Like many others she credits this development to the fissures of the age of revolutions. And like others, she sees this sense of change expressed especially in comments on the impact of new technologies. ${ }^{11}$

Alluring and convenient as this scheme may be, this chapter will argue that it is not only untenable but also unhelpful. The scholarly evidence

7 Peter Fritzsche, 'Spectors of history. On nostalgia, exile and modernity', American Historical Review 105 (2001/5), 1587-1618.

8 Terdiman. Present past, 3-4.

9 Frank Ankersmit, Sublime historical experience (Stanford: Stanford University Press, 2005), 321-324.

10 Peter Fritzsche, Stranded in the present. Modern time and the melancholy of history (Cambridge Mass: Harvard University Press, 2004); Fritzsche has been strongly influenced by George Lukács' observations on the genesis of the historical novel: The historical novel (Boston: Beacon Press, 1963).

11 Arianne Baggerman, 'Lost time. Temporal discipline and historical awareness in nineteenth-century Dutch egodocuments', in Arianne Baggerman, Rudolf Dekker and Michael Mascuch (eds.), Controlling time and shaping the self. Developments in autobiographical writing since the sixteenth century (Leiden and Boston: Brill, 2011), 455-535; Arianne Baggerman, “"Zo een vrijheid begeer ik nimmer meer te beleven”. Het witwassen van het verleden in Nederlandse ego-documenten (1800-1850)', De negentiende eeuw. Documentatieblad werkgroep rge eeuw 33 (2009), 74-95. 
that has been presented to support the notion of a memory crisis around 1800 has rarely paused to consider pre-180o evidence in any detail. As we will demonstrate in this article, once we do so, we discover responses to rupture and novelty that complicate the notion of a linear development in the history of historical consciousness. When we explore early modern memory cultures in their own right, we can see that they cannot be reduced to the simple shorthand of 'historia magistra vitae'. More importantly, they make us aware that the after-effects of rupture are not always as long lasting as many scholars have led us to believe. Our starting point for this argument will be a text that suggests that even in the revolutionary era, some contemporaries thought that the pace of change which they were experiencing was not unique. Furthermore, by examining sixteenthcentury evidence we will show that many of those who experienced the Reformation and great civil wars of the period experienced a sense of rupture that was actually as profound as that of their successors around 1800 and with quite similar results; the same melancholic nostalgia, the same impulse to preserve the relics and remains, are in evidence. Yet we will also show that in the 16oos these feelings did not, apparently, lead to a lasting sense of change. Instead, within a generation or so people reshaped their image of the past in such a way that it could be reintegrated with their present selves.

But if early modern Europeans could accomplish such reintegration, should we assume that the same feat would have been impossible for people in the 1800 s? We think these findings invite us to rethink the relationship between rupture and the development of historical consciousness. We will argue that we need to abandon linear histories of memory in favour of a history that leaves more room for the coexistence, both before and after 180o, of different ways of negotiating the relationships between past and present.

\section{Novelties and Their Precedents}

From the 1780 s to 1817 Jan Baptist Van der Straelen, a citizen of Antwerp in the Southern Netherlands, kept a private chronicle. ${ }^{12}$ Private chronicles (better known to some as Gegenwartschronistik) are situated somewhere

12 Jan Baptist van der Straelen, De kronijk van Antwerpen, ed. Floris Prims, 8 vols. (Antwerp: Maatschappij 'Voor God en 't Volk', 1929-1936). 
between 'life-writing' or 'egodocuments' and historiography. ${ }^{13}$ Their authors recorded noteworthy events on a day-to-day basis, as in a diary, yet without including events from their personal lives. ${ }^{14}$ Their primary aim was to document and safeguard historical events for posterity. The genre was widely practiced throughout the early modern era. For our purposes, the use of these, often quite mundane, chronicles, has the advantage of reflecting actual people's experiences and memory practices and allowing us to compare these over a long timeframe.

Jan Baptist Van der Straelen was born in 1761 into a wealthy family of old-regime civil servants. ${ }^{15}$ Unlike his father and his brother he did not pursue a career in administration but became an antiquarian, devoting his life to art and the study of history. He became a specialist in the history and artistic heritage of his native city of Antwerp. The chronicle he kept between his early twenties and his late fifties is revealing about his political and ideological orientation, and shows us Van der Straelen as a profoundly conservative man, who was a firm supporter of the existing order. ${ }^{16}$ He was confident that the wellbeing of society depended on the

13 Marc Blanchard, 'Fin de Siècle Living. Writing the Daily at the end of the renaissance', in Philippe Desan (ed.), Humanism in crisis. The decline of the French Renaissance (Ann Arbor, MI: The University of Michigan Press, 1991) 223-257; Elisabeth Bourcier, Les journaux privés en Angleterre de 1600 à 1660 (Paris: Imprimerie Nationale, 1976); Rudolf Dekker (ed.), Egodocuments and history. Autobiographical writing in its social context since the Middle Ages (Hilversum: Verloren, 2002); Bettina von Krustenstjern, 'Buchhalter ihres Lebens. Über Selbstzeugnisse aus dem 17. Jahrhundert', in Klaus Arnold et al. (eds.), Das dargestellte Ich. Studien zu Selbstzeugnissen des späteren Mittelalters und der frühen Neuzeit (Bochum: Winkler, 1999) 139-146.

14 Ursula Ewald, Studien zur Entwicklung der britischen Gegenwartschronistik im 17. und 18. Jahrhundert (diss., Heidelberg: Grosch, 1964); Robert A. Fothergill, Private chronicles. A study of English diaries (London and New York: Oxford University Press, 1974); James Amelang, The flight of Icarus. Artisan autobiography in early modern Europe (Stanford: Stanford University Press 1998), 22-51; Georges Gusdorf: 'Conditions et limites de l'autobiographie', in Günter Reichenkron and Erich Haase (eds.), Formen des Selbstdarstellung. Analekten zu einer Geschichte der literarischen Selbstportraits. Festgabe für Fritz Neubert (Berlin: Duncker und Humblot, 1956); Philippe Lejeune and Catherine Bogaert, Un journal à soi. Histoire d'une pratique (Paris: Textuel, 2003); Urs M. Zahnd, 'Stadtchroniken und autobiographische Mitteilungen. Studien zur Selbstdarstellung spätmittelalterlicher Bürger', in Arnold et al. (eds.), Das dargestellte Ich, 29-51. Jonathan Barry, 'Provincial town culture, 1640-1780. Urbane or civic? In Joan H. Pittock and Andrew Wear, Interpretation and cultural history (London; Macmillan, 1991), 198-234; Jeroen Blaak, Literacy in everyday life. Reading and writing in early modern Dutch diaries (Leiden: Brill, 2009), 189-264.

15 Johannes G. Frederiks and Frans J. van den Branden, 'Straelen (Jan Baptist van der)', in Idem, Biographisch woordenboek der Noord- en Zuidnederlandsche letterkunde (Amsterdam: Veen, 1888) 764; Floris Prims, 'Inleiding', in Van der Straelen, De kronijk, ed. Floris Prims, vol. 1, 7-14.

16 Brecht Deseure, 'Den ouden luijster is verdwenen. Geschiedenis, herinnering en verlies bij Jan Baptist Van der Straelen (1792-1817)', Belgisch Tijdschrift voor Nieuwste Geschiedenis $10(2010 / 4) 517-555$. 
conservation and maintenance of that order, which, throughout its long history, had become perfectly adapted to the people's needs and interests. The task of the present generations consisted in safeguarding the legacy of their ancestors and passing it on untarnished to their own offspring.

Underlying this conservatism was a quite distinctive relationship to the past, both before and after the Revolution. As any reader of Terdiman or Fritschze would expect, before the Revolution, Van der Straelen experienced the relationship between the present and the past as one of continuity. In his view, the present should reproduce the past by conforming to the models provided by history. Three elements in particular ensured this continuity: the old privileges and constitutions, the Catholic religion and the material remains of the past. They forged a bond, as it were, between the present people and their earliest history. The first element, the privileges and constitutions, formed the formal basis of old-regime society. They functioned according to the omnipresent logic of historical precedent, in which history was considered the ultimate source of legitimisation. The older the title, the better. 'Our old laws, privileges and customs', as Van der Straelen dubbed them, ensured the preservation of institutions and corporations, many of which had been functioning since the Middle Ages. No changes were to be introduced, lest the bond with the past be broken. Tellingly, Van der Straelen put great store in recording events that recurred on a yearly basis, such as processions, feast days or the renewal of public offices. Often he would mention the year in which the particular tradition was instated and emphasise that its observance had never been omitted since.

The second pillar of his bond with the past was the Catholic religion. This too was an ancestral heirloom which generation upon generation had passed on to its successors. Van der Straelen described: That old Roman Catholic faith, brought to our lands by the apostles and in which the inhabitants have been carefully brought up by their parents'. ${ }^{17}$ Like a string of beads it ran through the centuries and connected the present time to the earliest days of Christianity.

The final pillar consisted of the material remains of the past. As an antiquarian and a historian, Van der Straelen was an expert on the history of his city, the remains of which surrounded him on all sides. He read the townscape like a history book. Every façade, every church, every tomb and every coat of arms incarnated an element from that history. He did

17 Van der Straelen, De Kronijk, ed. Floris Prims, vol. 4, 238. 
not consider these elements the remnants of a dead past. On the contrary: they embodied it, safeguarded its memory and legitimised the existing order. As a consequence he greatly disapproved of any changes or acts of modernisation that threatened the material remains of the past because they endangered the link between the past and the present.

But of course, changes did come. Not surprisingly, Van der Straelen firmly condemned the revolution that took place in France. Not only did it topple the old regime of which he so thoroughly approved, but its antihistorical inspiration also jeopardised the legacy of the past. Great was his anxiety when the revolution suddenly came very close. In 1791 France went to war with Austria. As a result of the conflict the Southern Netherlands (part of the Austrian Habsburg possessions) were invaded and temporarily occupied by French troops. From 1794 on, the occupation became permanent. The Southern Netherlands were formally annexed to France and would remain so for the next twenty years. During these years the region was revolutionised from above. The old regime was abolished, and the existing structures of society were progressively dismantled.

Unsurprisingly for someone of his persuasion, and again in line with what Terdiman and Fritzsche have taught us, Van der Straelen experienced these developments as a disaster. His worst fears came true when the new French government abolished the old privileges and institutions, outlawed Roman Catholicism and started to systematically erase the material remains of the old regime. The pillars of Van der Straelen's sense of continuity with the past collapsed one by one. His desperate comments in the chronicle bespeak his fear of a complete break between the past and the present. Every time an institution or tradition was abolished, he bitterly looked back on its long history and lamented its demise. When the annexation by France was officially announced, he wrote: 'All good citizens were full of sadness because of these changes, and rightfully feared the complete downfall of the old constitution. Yes, one was greatly apprehensive of the introduction of all the French novelties'. ${ }^{18}$ The revolutionary measures indeed threatened to cut off every connection with the past. When the monasteries were dissolved and the parish churches began to be closed down, Van der Straelen wrote: 'And thus our religion and the public practice of that ancient Roman Catholic faith, preached in our lands from the time of the apostles on, ceases and is forbidden by its enemies.' 19

18 Ibid., vol. 5, 100.

19 Ibid., vol. 6, 118. 
Particularly unbearable for Van der Straelen was the attack on the material remains of the past. He experienced their disappearance as a double disaster, as his comments in the chronicle show. Not only did it threaten historical continuity, it also endangered the memory of the past itself. As the material supports of memory disappeared, whole chunks of history risked falling into oblivion. As historical landmarks were torn down, commemorative inscriptions were wiped out and noteworthy tombstones were smashed, the whole fabric of remembrance unraveled. Van der Straelen reacted by frantically recording every ancient object, text or building that had disappeared. In order to perpetuate the memory of the past, he made his chronicle the repository of all things lost. When the public display of religious symbols was banned, Van der Straelen scrupulously recorded every crucifix and saint's figure that was taken from view. Some of his friends went further and tried to salvage the confiscated objects themselves by illegally removing them. The chronicle contains many adventurous anecdotes of such attempts, including the clandestine opening of the mausoleum of the fifteenth-century countess Isabella of Bourbon so as to keep her earthly remains from falling into the irreverent hands of the revolutionaries.

All in all Van der Straelen's reaction to the revolutionary upheavals was very similar to those described by Fritzsche and others. The invasion of novelties he and his contemporaries faced, affected their perception of the relationship between the past and the present. Whereas these had formerly been connected by historical continuity, they now seemed to rapidly drift apart. Like many others Van der Straelen pointed out a change of times, a reversal in the temporal process. He typically experienced a sense of loss when confronted with the fundamental transformation of the world he had known. Again like many others, he stressed the newness of the revolutionary events, calling them 'unheard-of novelties'. He most powerfully expressed this feeling of novelty when commenting on the public auctioning of the furnishings of the Antwerp city hall, which included many objects of great historical and artistic value: 'Has anyone ever read about examples such as the ones perpetrated here today? Can similar things actually be found in the old chronicles?'. ${ }^{20}$

It is here that something surprising happens. Because Van der Straelen's answer to his own rhetorical questions was actually a resounding yes. Although Van der Straelen did cry out against the unheard-of character

20 Ibid., vol. 7, 95. 
of some revolutionary measures, most of them did not really strike him as unprecedented. To be sure, he called them 'new', meaning that they deviated from common practice. But they were not without historical parallels. Many of them echoed the calamities of the sixteenth century, when Antwerp had been a bulwark of the Protestant Reformation and civil war had raged in the Netherlands. When the Catholic clergy was being prosecuted by the new French government, Van der Straelen wrote: 'it seems as if the disasters and the unhappy times of the sixteenth century are coming here again'. ${ }^{21}$ When the public display of religious images was banned, he called it 'a second iconoclasm of 1566 ' ${ }^{22}$ Sometimes the parallels got very literal, as when the very same wonderworking statues or precious religious objects that had survived the Dutch Revolt had to be hidden away again, just as they had been in the sixteenth century. It was not only in religious matters that he found parallels with 'those sad and unhappy times', as he called them. All kinds of events turned out to be repetitions of sixteenth-century occurrences, despite their apparent novelty.

This finding has two important implications for our understanding of early modern memory. Firstly, Van der Straelen already had a well-developed sense of historical discontinuity before he personally experienced feelings of temporal change. Although he was a militant defender of the old regime and felt directly connected to a distant past, he was very well aware that time did not always move within the same cycle. He knew dramatic changes in the course of time had occurred before and could occur again. Secondly, he did not experience the crisis of his own time as something completely new and unprecedented. Actually, he could easily think of historical parallels. He did consider the changes produced by French occupation a rare disaster of extreme dimensions, but he did not consider them a unique event.

This picture is markedly at odds with Terdiman's and Fritzsche's account of the experience of time in Europe around 1800. If they are to be believed, contemporaries of the French Revolution had no choice but to feel suddenly and dramatically cut off from their own pasts. The example of Van der Straelen suggests that this is only partly true. By focusing exclusively on the experience of novelty, defenders of the modernity thesis seem to have lost sight of the persistence of other forms of making sense of change, including comparison with events from the past.

21 Ibid., vol. 4, 239.

22 Ibid., vol. 6, 87 . 
What should we deduce from this evidence? First, it is possible that the sense of total rupture between past and present which scholars have claimed accompanied modernity actually has to be sought later in the nineteenth or even in the twentieth century. There are certainly scholars who have suggested that it was events other than the French Revolution that caused the fissure between past and present. $^{23}$

\section{Pre-Modern Memory Crises}

Yet there is another possibility, too. Perhaps we need to rethink the relationship between experiences of rupture and historical consciousness. So far, scholars have assumed that the changes in notions about the past that are brought about by the experiences of rupture are irreversible. But is there really no alternative? To what extent can we assume that the loss experienced by a generation leads to irreversible changes in the historical consciousness of subsequent generations?

Pre-modern examples suggest that the long-term impact of experiences of rupture can be quite different. Crises of memory of the kind that Van der Straelen and his contemporaries experienced around 1800 were not new. The reactions of sixteenth-century chroniclers to the calamities of their time had been surprisingly akin to Van der Straelen's. As we will see, they too had feared the complete downfall of the old order. They too found themselves surrounded by novelties that seemed to threaten historical continuity. They too had felt cut off from the past as the present seemed to drift ever further away. Judging by this early modern evidence, however, it is our impression that the effects of dislocation can wear off quite soon, sometimes even within the people who experienced the loss.

In a path-breaking lecture of 1985 entitled the The Perception of the Past in Early Modern England, Keith Thomas described a much earlier transfor-

23 See for a useful overview of these timeframes Olick and Robbins, 'Social memory studies', and Jeffrey K. Olick, The politics of regret. On collective memory and historical responsibility (New York: Taylor \& Francis, 2007), 175-192; Pierre Nora et al., Les lieux de mémoire, Bibliothèque illustrée des histoires (Paris: Gallimard, 1984-1992). On the chronological indistinctiveness of the terms modern and pre-modern see Penelope Corfield, Time and the shape of history (New Haven: Yale University Press, 2007). 
mation in historical consciousness, in terms that are the spitting image of those used by Terdiman and Fritzsche:

The dramatic rupture with the medieval past occasioned by the Reformation created a sense of separateness and of an unbridgeable divide. This made it possible to perceive the recent past, not just as a collection of founding myths and precedents but as the embodiment of an alternative way of life and set of values. ${ }^{24}$

Using a range of sixteenth- and seventeenth-century sources Thomas pointed to a widespread nostalgia for the pre-Reformation past, when England had been 'merry', life had been simpler, and charity and hospitality abounded. Many lamented the lost abbeys and other sacred spaces of the Catholic world, and antiquarians set out to document their existence before the last traces had vanished. Margaret Aston had already shown that in England, this sense of loss resulted in a rush to salvage what remained. ${ }^{25}$ And since Thomas' lecture, the work of other scholars has presented much more evidence for this sense of dislocation. ${ }^{26}$ English Catholics, especially, experienced the break with the religious past in a very emotional manner:

The tyme hath been wee had one faith

And strode aright one ancient path

The thym is now that each man may

See new religions coynd each day

The tyme hath been the prelate's dore

Was seldome shotte against the pore

The tyme is now, so wives goe fine

They take not thought the kyne. ${ }^{27}$

This sentiment was not confined just to England. The changes brought about by the Reformations of the sixteenth century were momentous indeed, not only because they were accompanied by political shifts and religious wars, or because they divided families, but also because they called into question fundamental relationships between the living and

24 Thomas, The perception of the past, 9 .

25 Margaret Aston, 'English ruins and English history. The dissolution and the sense of the past', Journal of the Warburg and Courtauld Institutes 36 (1973), 231-255.

26 Adam Fox, 'Remembering the past in early modern England. Oral and written tradition', Transactions of the Royal Historical Society, 6th series, 9 (1999), 233-256; Alison Shell, Oral culture and Catholicism in early modern England (Cambridge: Cambridge University Press, 2007); Alexandra Walsham, The Reformation of the landscape. Religion, identity, and memory in early modern Britain and Ireland (Oxford: Oxford University Press, 2011).

27 Woolf, The social circulation, 340. 
the dead, the sacred and the profane, the material and the spiritual. It is no wonder that a sense of sudden change and of dramatic loss proved important incentives for many in sixteenth-century Europe to document their experiences. 'Nothing in the world remains certain. Nature does not persist in its own laws, and all laws lie in confusion', wrote Arnold Buchelius, a young man who had been born on the eve of the Dutch Revolt that within in a few decades would tear his world apart. Like Van der Straelen, he kept a chronicle of the events of his time, which ran from the years just before his birth in 1565 to the late 1590 , and he again recorded his everyday experiences in the 1620 s and ' 30 . As a consequence of the Revolt and the ensuing Reformation, he documented a strong sense of rupture and loss:

I suppose nothing at all has been done outside the usual and just order, when the ancient laws have been powerless [...] in the town of Utrecht, so that, with the council brought down, cobblers may rule [...]. While the common people live according to their own wishes [...] the feeble decrees of the inert council are changed with every hour. Hence right and wrong are put to similar uses and the widest door is open to every possible crime.

Like Van der Straelen, Buchelius had a large stake in the existence of the old order; as the illegitimate son of an Utrecht canon, he saw the Revolt destroy both the church in which his father had made his career and his own prospects for a career in the city's elite. He reported that: 'today, one may safely defame another man's reputation, thefts, too, go unpunished, deceit and perjury are profitable'. The social order had been turned upside down. ${ }^{28}$ Not only socially, but also in religion, everything had changed:

Our ancestors had one way to [the] true goal, those who live now have another. Now the altars of the saints have been overturned, the images and ornaments variously destroyed, many monasteries and churches lie torn down to their foundations. This is the eagerness of mortals for novelty [...].

The loss of the past moved him to start documenting the material remains which were under threat; he copied epitaphs, drew stained-glass windows, and described buildings, because:

[Protestants] neglect the monuments of the ancients and do not attend to the memorial masses of our ancestors, saying that their names have already

28 Judith Pollmann, Religious choice in the Dutch Republic. The reformation of Arnoldus Buchelius, 1565-1641 (Manchester: Manchester University Press, 1999), $5^{2}$. 
been written in heaven, so that some of them seem more barbaric than the Goths themselves. ${ }^{29}$

He spent the rest of his life as an antiquarian scholar, documenting the past, and also clearly aware of the enormity of this task. People thought he had nothing to do, he wrote in 1632:

But they not know what it is like to deal with books, and to digest the acts of so many thousands of years or to let one's mind run over so many changes, mutations, conditions, great events of peoples, kingdoms and provinces. There is no greater immensity than this. ${ }^{30}$

Just as for so many who experienced the age of revolutions, the experience of rupture had thus resulted not only in a sense of loss but also in an acute awareness of the risks of oblivion and an agenda for action to counteract these threats. Buchelius became a historian with a keen sense for the 'mutations' in history.

Yet if Buchelius' experiences seem to confirm that experiences of rupture can make people painfully aware of the differences between past and present and lead to a nostalgic interest in the world of the past, his example also shows that the impact of rupture is not necessarily of lasting significance for the way in which people experience the past. Because Buchelius' nostalgia about the Catholic past did not last; he soon began to appropriate the notion that the changes which his society had witnessed had in fact been for the good. He became a Protestant, first reluctantly so, but later a real hardliner. At some point in his life he literally crossed out the angry poems about the Revolt that he had written as a youngster. Buchelius always remained a deeply conservative man, yet his notion of what was to be conserved underwent a transformation; in the 1580 , he had bemourned the Reformation but in the 1620 s he was idealizing the early phases of Revolt and Reformation. 'Oh poor Republic', he exclaimed about the new state whose founding he had once deplored, 'that once flourished but now lies trampled under the feet of the same men who disregard the benefits they have reaped, and with shameless prevarication try their hardest to suppress the hereditary liberty.' ${ }^{31}$

His nostalgia thus remained, but it associated itself with another picture of the past, which enabled him to reconcile it with his identity in the present. If this sort of transformation can happen within a generation, it is

\footnotetext{
29 Ibid., 86.

30 Ibid., 191.

31 Ibid., 151-152, 162.
} 
no wonder that the children and grandchildren born to those traumatised by dislocation end up integrating many of 'new' developments into their picture of the 'old' order. Thus, it took Calvinists in England and the Dutch Republic only a generation to start defending what they now considered to be their 'old' religion against the challenges of 'novelties' imposed by the Arminian party. ${ }^{32}$ After the disruptions of war, people nevertheless found ways to re-imagine their histories as a continuum. ${ }^{33}$ The past itself is not ignored, but it is re-imagined to suit our present needs.

\section{Conclusion}

Feelings of temporal change and discontinuity can hardly be called distinctively modern, and they were part and parcel of early modern experiences of time. In their search for the progressive modernisation of Western historical consciousness, scholars have tended to over-emphasise the uniqueness of the memory crisis of around 1800. As it acquired the status of a watershed between pre-modern and modern ways of making sense of the past, it came to be considered as a completely new event. This mechanism has obscured the many parallels between this crisis and its early modern predecessors. In fact, the French Revolution caused what was only one in a series of memory crises. Acknowledging this, of course, has consequences for our assumptions about the relationship between rupture, modernity and a sense of the past. Because if earlier memory crises had not led to the birth of 'modernity', we can no longer assume that it was such a crisis of memory that, in and by itself, can be credited with the emergence of a modern worldview around $1800 .^{34}$

What are the alternatives? Some scholars have tried to trace the advent of modern historical consciousness to earlier moments of crisis. In the last decades early modernists have been keen to stress the early modern origins of several of the traditional accessories of modernity. This has led to more refined chronologies that credit the Reformation, the sacco di Roma, Puritanism or the English Civil Wars with bringing about a modern aware-

32 Charles H. Parker, 'To the attentive, nonpartisan reader. The appeal to history and national identity in the religious disputes of the seventeenth-century Netherlands', The sixteenth century journal 28 (1997), 57-78.

33 For another example see e.g. Karel Degryse, Pieter Seghers. Een koopmansleven in troebele tijden (Antwerpen and Baarn: Hadewijch, 1990).

34 E.g. Berman, All that is solid, 17; Terdiman, Present past, 3-5. 
ness of change. ${ }^{35}$ Yet how helpful is it to keep looking for a 'modern turn' in the history of historical consciousness? The incompatibility of these alternative chronologies, for one thing, suggests it is not. The linear thinking underlying these quests for origin favours schemes of development in which new ways of making sense of the past replace older ones. In reality, however, several of these attitudes can coexist at the same time or dis- and reappear. As the example of Buchelius shows, it is possible for one and the same person to bemourn the past one moment and embrace change the next.

The existence of a crisis of memory around 1800 as well as its early modern and possibly even medieval predecessors cannot be denied. People's relationships with the past were indeed deeply shaken. Very real feelings of a break between the past and the present were shared by many. There can also be no doubt that experiences of change have influenced the way in which people experience the relationship between past and present. Yet these experiences of transformative change were neither unique, nor need we assume that they necessarily had a lasting impact on people's perceptions of the world. Rather, our examples suggest that there are other ways of accommodating change. We do not want to claim that the responses of Van der Straelen or Buchelius are typical, or the only possible, reactions to rupture. Van der Straelen tried to frame and interpret his experiences by placing them in a historical perspective, as have many others since his time. As Eric Hobsbawm pointed out in 1972, one of the interesting and quite unexpected characteristics of modernity is the ongoing interest in the past. ${ }^{36}$ Buchelius' example suggests a second response, which is to accommodate and integrate the new by reimagining the past and remaking it into a shape that accords with the needs of the present. Together, these cases suggest we need to think less in terms of linear and irreversible changes when considering the history of memory and instead be aware that different ways of negotiating the past, or modes of thinking about it, can coexist, not just in societies but indeed in individuals.

35 John G.A. Pocock, 'The origins of the study of the past. A comparative approach', Comparative Studies in Society and History 4 (1961-1962), 209-246; Jo Tollebeek, 'De conjunctuur van het historisch besef', in B. Raymaekers and D. Van Riel (eds.), De horizonten van weten en kunnen (Leuven: Universitaire Pers Leuven, 2002), 167-193; Woolfe, The social circulation.

36 Hobsbawm, 'The social function of the past. Some questions'. 